\title{
The Role of Narrative Intelligence in English Language Teaching, Major and Gender
}

\author{
Reza Pishghadam \\ English Department, Ferdowsi University of Mashhad, Iran \\ Seyyed Ehsan Golparvar \\ Ferdowsi University of Mashhad \\ Gholam Hassan Khajavy \\ Ferdowsi University of Mashhad
}

Received: 30 November $2011 /$ Accepted: 5 April 2012

ISSN: $1697-7467$

\begin{abstract}
This research attempt purports to examine the role of narrative intelligence in the success of English language teachers with respect to major and gender. Seven hundred and fifty three English language teachers and learners took part in this study. Scales of narrative intelligence and teacher success were used to garner data in this study. The findings indicated that there exists a significant relationship between teachers' pedagogical effectiveness and their narrative intelligence. Moreover, EFL teachers who majored in English literature showed a higher level of narrative intelligence. In addition, there was no statistically significant difference between male and female teachers in terms of narrative intelligence. Finally, the results were discussed and pedagogical implications were provided in the context of language learning and teaching.
\end{abstract}

Keywords: major, gender, narrative intelligence, EFL teacher, pedagogical success

El papel de la inteligencia narrativa en la enseñanza de inglés, asignaturas maior y género

RESUMEN: Este intento de investigación pretende examinar el papel de la inteligencia narrativa en el éxito de los profesores de inglés y en sus mayores en hombres y mujeres. Setecientos cincuenta y tres profesores de inglés y los alumnos participaron en este proyecto. Las escalas de inteligencia narrativa y el éxito docente se utilizaron para reunir datos de este estudio. Los resultados indicaron que existe una relación significativa entre la eficacia pedagógica de los docentes y su inteligencia narrativa. Por otra parte, profesores de inglés que se especializó en la literatura Inglés mostraron un mayor nivel de inteligencia narrativa. Además, no hubo diferencia estadísticamente significativa entre los maestros y maestras en términos de inteligencia narrativa. Finalmente, los resultados fueron discutidos y las implicaciones pedagógicas se presentaron en el contexto del aprendizaje de idiomas y la enseñanza. Palabras clave: especialización, género, inteligencia narrativa, enseñanza del inglés como lengua extranjera, éxito pedagógico. 


\section{INTRODUCTION}

Teachers are one of the significant factors which can hugely impact the process of learning and teaching (Baydala, Rasmussen, \& Sherman, 2004). They can motivate, encourage, and help learners to be as successful as possible (Porter \& Brophy, 1988). Teacher quality is considered to be the strongest predictor of students' learning (Galluzzo, 2005). Therefore, students' success or failure to a great extent hinges on teachers' ability. Based on this, the concept of teacher success has attracted the attention of many researchers in the field of second/foreign language teaching. Bulks of studies have been conducted to examine teacher effectiveness (e.g., Black \& Howard-Jones, 2000; Covino \& Invanicki, 1996; Elizabeth, May, $\&$ Chee, 2008). Also, other studies have tried to explore the factors that may be associated with teacher success, such as English language teacher competency (Pishghdam \& Khosropanah, 2011), self-efficacy (Ghanizadeh \& Moafian, 2011), multiple intelligences (Pishghadam, Moafian, 2008), or the use of NLP (Neurolinguistic Programming) techniques (Pishgadam, Shayesteh, \& Shapoori, 2011). In a comprehensive study, Elizabeth, May, and Chee (2008) suggested a model explaining the factors that may influence teacher success, among them clear and in-depth delivery of the lesson and the ability to enhance students' understanding. These two factors are closely related to Randall (1999) concept of narrative intelligence, which is defined as the ability to produce and understand narratives. Due to its nature, which mostly deals with interpersonal and intrapersonal competencies, it seems that teachers who have a higher amount of narrative intelligence can be more successful in teaching.

Consequently, delving into the probable association between narrative intelligence and teacher success can illuminate the factors affecting teacher success. Moreover, in some countries like Iran teachers from different majors are allowed to teach English. The only criterion for their recruitment may be their high level of language proficiency. Thus, in this study we also like to see whether EFL teachers' major can contribute to their success with regard to narrative intelligence. Finally, we like to explore the role of gender in EFL teachers' success in light of narrative intelligence.

\section{THEORETICAL FRAMEWORKS}

Human beings employ narratives to make sense of the world around them (Booth, 1988; Bateson, 1989; Bruner, 1987; Randall, 1999). Steele (1986) considers narrative intelligence as an active ability to produce a story. Randall (1999) states that narrative intelligence, related to biographical aging, is both to produce and understand (follow) the story of our own life. Randall (1999) pointed out that narrative intelligence involves some interrelated sub-categories that are instinctive in our attempt for constructing the reality. The first subcomponent of narrative intelligence is narration. Based on Randall (1999: 17), "narration is to convey to others what is going on, has gone, or may go on, sensitive to what they understand in terms of 'logical connection' between events, causes, consequences, etc'. Bruner (1987) believed that narration requires communicating the element of interest to the task of storytelling by considering such factors as grammar, vocabulary, rhetoric, and 
intonation and making them appropriate to the linguistic context of the narrative. A good narrative summarizes the main action while capturing its central dynamic of development and denouement, matches the tastes of the audience. It includes neither too much detail nor too little (Kerby, 1991, Labov, 2001; Randall, 1999).

The second subcategory of narrative intelligence is thematization that refers to the ability to recognize the theme of a narrative, i.e., its main idea, from the recurrent patterns of meaning observed in that narrative (Randall, 1999). An intelligent narrator can also understand how these recurring patterns are developed and resolved. Thematization is defined as being aware of recurrent patterns in the events or situations of a narrative (Birren \& Dutchman, 1991). Thematization also includes identifying motifs or symbols and theorizing about their relevance, and understanding the theme, the central point, of a narrative (Randall, 1999).

The third sub-component of narrative intelligence is emplotment. It includes editing and summarizing what has happened in the past or what is currently happening, and resolving conflicts or problems. Another characteristic of emplotment is prioritizing, which is selecting some details as more important than others. Emplotment also considers events of life as temporal units with beginnings, middles, and endings (Randall, 1999).

Characterization, the fourth subcategory of narrative intelligence, is the ability to form a picture of ourselves and others. Human beings form a picture of how they and others are like by turning to various cues and clues. Randall (1995) emphasized the importance of a dynamic approach to characterization, which means continuous reformulation of our perception of how others are like in view of new pieces of evidence as the narrative is cited. Stories that focus on conflict are usually characterized by giving responsibility for events and contrasting characters as protagonists and antagonists.

The fifth sub-capacity of narrative intelligence is genre-ation. Bruner (1998) stated that narration is an important feature of storytelling because it provides a framework for grasping human experience. According to Randall (1999) genre-ation refers to organization of events. Bruner (1996) considered a genre as a series of particular events that are fundamentally ironic, tragic, comic, and so force. Genre-ation involves making the difference between a good mood and a bad mood, making sense of the narrative tone, and understanding human experience in a dramatic shape.

With respect to teacher success different definitions have been proposed. Brown and Marks (1994) stated that successful teachers examine their own teaching experience and that of others. It makes them become more aware of the strong and weak points in their teaching experience; put another way, they conduct critical investigation of their teaching performance in the classroom (cited in Ghanizadeh \& Moafian, 2011). Brookfield (1995) mentioned some of the characteristics of a successful teacher, including making use of a wide range of instructional strategies, teaching at an appropriate pace, checking students' comprehension and involvement, concentrating on the topic and its educational objectives, and making use of humor. Anderson (2004) defined effective teacher as the one who achieves the intended goals, either set by themselves or by others; this definition implies that effective teachers should possess the required knowledge and skills to achieve the intended goals.

Elizabeth et al. (2008) set out a model for defining teacher success in which they proposed that for defining teacher success, not only should we pay attention to personal and professional qualities, but also we should take contextual factors -such as teachers' personal context, school context, and context beyond school- into account. They also presented a 
number of personal characteristics like patience, sense of responsibility, caring for students, and enthusiasm as personal qualities. Regarding professional qualities, they pointed to factors such as clear presentation of the instructional material, the ability to enhance students' understanding, motivating students, and effective classroom management.

Among studies done on teacher success, Pishghadam and Moafian (2008) explored the association between multiple intelligences and teacher success, concluding that interpersonal, interpersonal, and kinesthetic intelligences can play significant roles in teacher success. In another study, Ghanizadeh and Moafian (2011) showed that there is a significant relationship between EFL teachers' self-efficacy and their success. Moreover, Pishghadam, Shayesteh, and Shapoori (2011) found a relationship between using NLP techniques and teacher success. However, the contribution of narrative intelligence to teacher effectiveness has not been widely researched. Thus, the present research tries to answer the following research questions:

1. Is there any significant association between EFL teachers' narrative intelligence and their success in teaching?

2. Are there any significant differences in narrative intelligence among EFL teachers with different majors?

3. Are male and female EFL teachers are significantly different in terms of narrative intelligence?

\section{3. Меthod}

\subsection{Participants}

The total population participated in this study consisted of 753 English teachers and students from different English language institutes in Mashhad, Iran. Teachers' age ranged from 21 to 52 (mean=26.46, $\mathrm{SD}=4.21$ ) and learners' age ranged from 14 to 36 (mean=21.34, $\mathrm{SD}=2.18$ ). It should be noted that all the teachers who participated in this study had different fields of study; nevertheless the majority of them had majored in the various branches of English, such as English Teaching as a Foreign Language $(\mathrm{N}=26)$, English Literature $(\mathrm{N}=23)$, or English Translation $(\mathrm{N}=20)$. It is worth mentioning that EFL teachers in Iran are authorized to teach English from different disciplines. In this study 11 teachers had majors other than English (e.g., engineering). The EFL students taking part in this study spoke Persian as their mother tongue and their language proficiency varied from elementary to advanced level.

The reason that we have chosen teachers from private language institutes rather than public schools is that teachers in public schools are permanently employed in Iran. Hence they are not worried about losing their jobs. In contrast, teachers in private language institutes do not enjoy permanent employment. Consequently, their employers place considerable pressure on them to be more effective and innovative. Furthermore, there is no competition between these schools to attract more students because education in these schools tends to be free of charge. Nonetheless, private language institutes go into a tough competition with each other $b$ to attract more language learners. Moreover, system of education is centralized in Iran`s public schools; all decisions are made by the government, teachers just do 
and teach the books and the materials provided by the authorities in charge, while system of education in private language schools is decentralized; teachers have more options and freedom to select their own materials.

\subsection{Instrumentation}

To measure the narrative intelligence of the teachers along with their success, we employed two instruments:

\subsubsection{Narrative Intelligence Scale (NIS)}

To measure the narrative intelligence of the EFL teachers participating in this study, the NIS (Pishghadm, Baghaei, Shams, \& Shamsaee, 2011) was utilized. This instrument consists of 35 items. A score of 1 to 5 is allocated to each item, yielding a score range of 35 to 175. With regard to content validity, Pishghadam et al. (2011) developed this scale according to the guidelines proposed by Randall (1999). To ensure the construct validity of this instrument, Pishghadam et al. (2011) made use of the Rasch model. The findings produced by the Rasch model indicated that all items, except for six ones, meet the unidimentionality criterion. This measurement produced an item reliability of .99 and a person reliability of 98. In the present research, Cronbach's alpha for this scale was .83 .

The EFL teachers' narrative intelligence was assessed by eliciting and measuring their narrative performance in two narrative tasks. The first task was the narrative reconstruction task. Answering this task required looking at and narrating a six-step picture story. It was about a man who got sick but was reluctant to go to a doctor because it was expensive. In the end, he became extremely ill and was sent to hospital, and he had to spend much more money than the amount of money he had to spend initially. Fulfilling this task took around 5 minutes. Task 2, the personal narrative task, was based on the prompt "please tell the story of your first day at university". Performing the second task also took five minutes.

\subsubsection{Characteristics of Successful Teachers Questionnaire (CSTQ)}

The present study is organized based on the model for a successful EFL teacher suggested by Moafian and Pishghadam (2009) who developed and validated the CSTQ. The data they gathered and analyzed produced 12 factors for teacher success as a construct that are: (1) teaching accountability, (2) interpersonal relationships, (3) attention to all, (4) examination, (5) commitment, (6) learning boosters, (7) creating a sense of competence, (8) teaching boosters, (9) physical and emotional acceptance, (10) empathy, (11) class attendance, and (12) dynamism.

CSTQ consists of 47 five-point Likert-type items ranging from 'strongly agree' (5) to 'strongly disagree' (1) producing a score between 47 and 235. Answering all items takes 30 minutes. Exploratory factor analysis has ensured the construct validity of the questionnaire, and the total reliability of the questionnaire has been .94. Running Cronbach's alpha, the reliability of this scale for the present study was .89 . 


\subsection{Procedure}

In this study data collection took 4 months. To measure the narrative intelligence of the teachers, they were asked to take a look at a picture story and then recount the story (Task 1). After that, the researchers asked the teachers to tell the story of their first day at university (Task 2). In both tasks, participants were required to tell the story in their mother-tongue (Farsi). The participant's narrative performance was recorded by the researchers. Following this, the CSTQ was administered to the language learners to assess their English teachers' success.

In order to measure the relationship between teacher success and narrative intelligence and its components, Pearson correlation was run. In order to investigate the possible difference in narrative intelligence in EFL teachers with different majors, One-way ANOVA was calculated. In this analysis, there were four groups of teachers in terms of their major, namely teachers who majored in English literature, TEFL, English translation, and those who majored in other fields of study. Finally, to examine the difference between male and female EFL teachers in terms of narrative intelligence, Independent Samples t-test was run.

\section{RESUlts}

To answer the first research question, Pearson correlation was computed. Table 1 demonstrates the results of the correlational analysis.

Table 1. The results of the correlation analysis between narrative intelligence and teacher success.

\begin{tabular}{lccccccc}
\hline & Emplot. & Character. & Narration & Genre-ation & Them. & Total NI & T. Success \\
\hline Emplotment & 1 & $.632^{* *}$ & $.581^{* *}$ & $.470^{* *}$ & $.479^{* *}$ & $.888^{* *}$ & $.292^{* *}$ \\
Characterization & 1 & $.448^{* *}$ & $.438^{* *}$ & $.466^{* *}$ & $.744^{* *}$ & .198 \\
Narration & & & 1 & $.620^{* *}$ & $.447^{* *}$ & $.745^{* *}$ & $.355^{* *}$ \\
Genre-ation & & & & 1 & $.466^{* *}$ & $.753^{* *}$ & $.498^{* *}$ \\
Thematization & & & & & 1 & $.711^{* *}$ & $.249^{*}$ \\
Total NI & & & & & 1 & $.413^{*}$ \\
Teacher success & & & & & & 1 \\
\hline
\end{tabular}

$* \mathrm{p}<.05, * * \mathrm{p}<.01$

As Table 1 exhibits, there exists a moderate correlation between Total Narrative Intelligence (Total NI) and teacher success $(\mathrm{r}=.413, \mathrm{p}<.05)$. Among the subscales of narrative intelligence, there are moderate correlations between teacher success and emplotment $(r=.292$, $\mathrm{p}<.05)$, narration $(\mathrm{r}=.355, \mathrm{p}<.05)$, genre-ation $(\mathrm{r}=.49, \mathrm{p}<.05)$, and thematization $(\mathrm{r}=.24$, $\mathrm{p}<.05$ ). It is interesting to note that genre-ation has the highest correlation coefficient with teacher success $(\mathrm{r}=.49, \mathrm{p}<.05)$, and characterization has the lowest correlation coefficient with teacher success $(\mathrm{r}=.19, \mathrm{p}>.05)$.

In order to answer the second research question concerning the possible difference in narrative intelligence among teachers who have different majors ANOVA was run. The 
EFL teachers participating in this research project were divided into four groups in terms of academic major, namely those majoring in English literature, TEFL, translation, and those majoring in other fields. Table 2 shows the results of ANOVA for these four groups.

Table 2. Results of one-way ANOVA for narrative intelligence with regard to EFL teachers' majors.

\begin{tabular}{lccccc}
\hline & Sum of Squares & df & Mean Square & F & Sig. \\
\hline Between Groups & 281.522 & 3 & 193.841 & 1.280 & .000 \\
Within Groups & 1151.365 & 76 & 151.465 & & \\
Total & 12092.887 & 79 & & & \\
\hline
\end{tabular}

According to Table 2, there exists a significant difference among the four groups in terms of Total NI score $(\mathrm{F}=1.280, \mathrm{p}<.05)$. The analysis of variance showed just the difference among the four groups, but in order to locate the differences Scheffe Post HOC test was run. Table 3 shows the results of Post Hoc comparison.

Table 3. The results of Scheffe Post Hoc test for narrative intelligence with regard to EFL teachers' majors

\begin{tabular}{lccccc}
\hline Major & $\mathbf{N}$ & $\mathbf{1}$ & $\mathbf{2}$ & $\mathbf{3}$ & $\mathbf{4}$ \\
\hline Literature & 23 & 94.02 & & & \\
Translation & 20 & & 87.90 & & \\
TEFL & 26 & & & 81.51 & \\
Other & 11 & & & & 79.39 \\
Sig & & 1.000 & 1.000 & 1.000 & 1.000 \\
\hline Subset for alpha $=.05$ & & & &
\end{tabular}

Scheffe Post Hoc test demonstrated that those EFL teachers who majored in English literature had the highest level of narrative intelligence (mean $=94.02$ ), those EFL teachers whose major was translation were the second highest group (mean $=87.90$ ), those EFL teachers majoring TEFL were the third group (mean $=81.51)$, and those EFL teachers who had other majors (e.g., engineering) showed the lowest level of narrative intelligence (mean $=79.39)$.

\section{Literature Major > Translation Major > TEFL Major > Other Majors}

The third research question is concerned with the possible difference between male and female EFL teachers with regards to their narrative intelligence. In order to answer this question, independent samples t-test has been calculated. Table 4 depicts these two groups of teachers' means on the NIS. 
Table 4. Independent samples t-test for narrative intelligence in male and female teachers.

\begin{tabular}{lccccc}
\hline Group & N & Mean & df & t-value & Sig \\
\hline Male & 42 & 88.97 & 78 & -.748 & .183 \\
Female & 38 & 91.05 & & & \\
\hline
\end{tabular}

According to Table 4, the mean score of narrative intelligence for male teachers is 88.97 and that of female teachers is 91.05 . However, the difference between these two groups is not statistically significant $(\mathrm{t}=-.748, \mathrm{p}>0.05)$. Therefore, male and female EFL teachers participating in this study are rather similar in regards to narrative intelligence.

\section{Discussion}

As already mentioned, this study attempted to answer three questions. The first question was about the association between EFL teachers' narrative intelligence and their success. The second research question examined whether EFL teachers from diverse majors were different with regard to narrative intelligence. Finally, the third question investigated the possible difference in narrative intelligence between male and female EFL teachers.

Regarding the first research question, we found that there exists a significant association between teacher success and narrative intelligence. It goes without saying that teachers who know how to convey knowledge in an English language learning class can be more successful. Teachers who know how to commence, maintain, and terminate the class can considerably motivate learners to follow the syllabus closely, getting less deviated from the main road of learning (Bruner, 1987, 1996; Randall, 1999). Furthermore, as a good narrator knows when to empathize with the listeners, effective teachers also try to guess at probable problems students might face in the process of learning, providing the necessary solutions to them (Gardner, 1993). This implies that transmitting knowledge requires a great amount of narrative intelligence.

Moreover, the outcomes demonstrated that out of the subscales of narrative intelligence, genre-ation was found to be highly correlated with teacher success. Genre-ation refers to "organizing events into more or less predictable patterns or types in both telling and experiencing them" (Randall, 1999: 18). Based on this definition, we can conclude that successful teachers know well how to organize their class in a way that everything goes smoothly. Besides, a good narrative must be sensitive to the tone of the characters (Randall, 1999), implying that teachers must sensitize themselves to the students' feelings. This is in line with findings of Fahim and Pishghadam (2007), who claim that effective language learning is closely tied to emotional competencies. Thus, teachers are to monitor students ' feelings regularly, providing the appropriate feedback in due time.

With regard to the second research question, the outcomes of this study revealed that EFL teachers who majored in English literature showed a higher level of narrative intelligence and therefore more successful in teaching. One possible line of explanation can be that they are more exposed to literary texts than those EFL teachers majoring in TEFL, translation, or other fields of study. Being exposed to works of literature, in which emplotment, characterization, 
genre-ation, narration, and thematization are more prominent in comparison with non-literary texts; may seem to have a positive influence on literature-majoring EFL teachers.

Moreover, surprisingly we found that that EFL teachers majoring in TEFL have not done their job properly. This might imply that EFL teacher education programs held at universities in Iran may not provide EFL teachers with necessary equipment to achieve pedagogical effectiveness. Or, it can be assumed that teachers' language proficiency and/or personality traits play a more significant role in their pedagogical success than the kind of knowledge they obtain in EFL teacher education programs. This finding can be justified in the context of language education in Iran. MA and Ph.D. students of TEFL are generally exposed to theoretical aspects of teaching, disregarding the practical issues. The classes are usually characterized by lectures, given either by professors or by students. In these programs, students are provided with the knowledge about language teaching rather than the skill of teaching a foreign language. Thus, students are expected to be erudite scholars rather than good teachers. Therefore, they are not given the opportunity to acquire and demonstrate the ability to teach a foreign language in EFL teacher education programs.

Furthermore, TEFL programs in Iran are quintessentially research-based. Graduate students are expected to write research articles rather than to acquire EFL teaching skills. In other words, they are supposed to be researchers rather than efficient teachers. It should be noted that this trend has been overemphasized in recent years. The nature and topics of the research projects conducted by graduate TEFL students are also of considerable importance. The majority of these research attempts are quantitative by nature. Students administer questionnaires and perform some statistical calculations. Evidently, carrying out such projects do not yield pedagogical benefits for TEFL students.

In this regard, there appears to be a sharp contrast between TEFL students and literature students. MA programs in English literature are far less research-based in comparison with TEFL programs. Although students of English literature are not exposed to EFL theories, they, as EFL teachers in language institutes, may be more concerned with establishing a good relationship with their language learners. This may lie in the fact that literature students pay close attention to building a constructive relationship with literary texts and their authors. Another possible line of explanation can be that students of English literature, who showed a higher level of narrative intelligence in this study is that their professors might be more narratively intelligent than TEFL professors. It is logical to assume that the narrative ability of professors can be transferred to students.

Finally, this study showed no significant difference in narrative intelligence between male and female EFL teachers. In other words, gender is not a factor distinguishing narrative intelligence in EFL teachers. Of course, more investigations are required to ensure the validity of this particular finding.

\section{Conclusion}

The outcomes of this study showed that narrative intelligence plays a significant role in EFL teachers' effectiveness. It was also indicated that narrative intelligence has been distributed unevenly among different majors. Moreover, it was found that gender does not play any role in teacher success with respect to narrative intelligence. In a nutshell, genre-ation was 
found to be highly correlated with teacher success and teachers majoring in literature were much more successful than teachers majoring in translation, TEFL, or other disciplines.

Based on the results of this study, the following implications are put forward. First, the role of narrative schooling and literacy is highlighted in the context of foreign language learning and teaching. EFL teachers are to note that teacher success and narrative intelligence are intertwined. Thus teachers are expected to get familiarized with the subscales of narrative intelligence, trying to enhance this ability within themselves. Second, the theoretical part in the syllabus of teacher training courses should embrace discussions on narrative intelligence and how to carry it out in the class. With regard to the employment efficient EFL teachers, language schools and institutes are recommended to include narrative performance as one of the cornerstones of recruiting effective instructors. Further, due to the low level of narrative intelligence observed in EFL teachers majoring in TEFL and with the positive role of narrative ability in teacher effectiveness in mind, major theoretical and practical reconsiderations are recommended to be implemented in EFL teacher education programs held at universities. Finally, EFL teacher education programs need to be more practice-based. In other words, they should distance from bombarding students with theories, striving hard to equip students with practical teaching skills. These programs should also create opportunities in which graduate students can practice and display the skills they have acquired in classroom-like conditions.

In this study the informal context was analyzed, another study can be conducted to examine the role of narrative intelligence in pedagogical success in the formal context. Since this study was carried out in language institutes in Mashhad, a city in Iran, its results cannot be safely generalized to other EFL contexts. Moreover, in this study EFL teachers' experience was not taken into account as variables which can be the subject of further inquiries. In addition, future research can analyze the types of feedback EFL teachers give to their learners in light of their narrative intelligence. Furthermore, interested researchers can investigate university professors' narrative literacy and the effect it may exert on students' language teaching experience.

\section{Acknowledgement}

We gratefully appreciate the help of miss Iran Rad, who patiently collected the data from different language institutes in Mashhad in 2011. We also thank all teachers and students who willingly participated in this project.

\section{ReFERENCES}

Anderson, L.W. (2004). Increasing Teacher Effectiveness. Paris: UNESCO, IIEP.

Bateson, M.C. (1989). Composing a Life. New York: Atlantic Monthly.

Baydala, L., Rasmussen, C. and Sherman, J. (2004). "The impact of teacher factors on achievement and behavioral outcomes of children with Attention Deficit/Hyperactivity Disorder (ADHD): a review of literature", in Educational Research, 50: 347-360. 
Birren, J. E. and Dutchman, D. E. (1991). Guiding Autobiography Groups for Older Adults: Exploring the Fabric of Life. Baltimore, MD: The John Hopkins University Press.

Black, R. S. and Howard-Jones, A. (2000). "Reflections on best and worst teachers: An experiential perspective of teaching", in Journal of Research and Development in Education, 34: $1-12$.

Booth, W. (1988). The Company We Keep: An Ethics of Fiction. Berkeley: University of California Press.

Brookfield, S. (1995). Becoming a Critically Reflective Teacher. San Francisco: Jossey Bass.

Bruner, J. (1987). "Life as narrative", in Social Research, 54: 11-32.

Bruner, J. (1996). The Culture of Education. Cambridge, MA: Harvard University Press.

Bruner, J. (1998). "What is a narrative fact?", in Annals of the American Academy of Political and Social Science, 560: 17-27.

Celik, S. (2011). "Characteristics and competencies for teacher educators: Addressing the need For improved professional standards in Turkey", in Australian Journal of Teacher Education, 36: 73-87.

Covino, E. A. and Inwanicki, E. F. (1996). "Experienced teachers: Their constructs of effective teaching.", in Journal of Personnel Evaluation in Education, 10: 325-363.

Elizabeth, C. L., May, C.M. and Chee, P.K. (2008). "Building a model to define the concept of teacher success in Hong Kong”, in Teaching and Teacher Education, 24, 623-634.

Fahim, M. and Pishghadam, R. (2007). "On the role of emotional, psychometric, and verbal intelligences in the academic achievement of university students majoring in English language", in Asian EFL Journal, 9: 240-253.

Galluzzo, G. R. (2005). "Performance assessment and renewing teacher education", in Clearing House, 78: 142-145.

Gardner, H. (1993). Multiple Intelligences: The Theory in Practice. New York: Basic Books.

Ghanizadeh, A. and Moafian, F. (2011). "The relationship between Iranian EFL teachers' sense of self-efficacy and their pedagogical success in language institutes", in Asian EFL Journal, 17: 249-272.

Kerby, P. A. (1991). Narrative and the Self. Bloomington: Indiana UP.

Labov, W. (2001). Uncovering the Event Structure of Narrative. Georgetown University Round Table.

Moafian, F. and Pishghadam, R. (2009). "Construct validation of a questionnaire on characteristicsof successful EFL teachers", in Pazhuhesh-e Zabanhe-ye Khareji Journal, 54: 127-142.

Pishghadm, R., Baghaei, P., Shams, M. A. and Shamsaee, S. (2011). "Construction and Validation of a Narrative Intelligence Scale with the Rasch Rating Scale Model”, in The International Journal of Educational and Psychological Assessment, 8: 75-90.

Pishghadam, R., Baghei, P. and Shayesteh, H. (2012). "Construction and validation of English language teacher creativity scale (ELTCS)", in Journal of American Science, 8: 497-508.

Pishghadam, R. and Khosropanah, F. (2011). "Examining construct validation of the English language competency test”, in International Education studies, 4: 194-209.

Pishghadam, R. and Moafian, F. (2008).“The role of Iranian EFL Teachers' multiple Intelligences in their success in language teaching at High schools", in Pazhuhesh-e-Zabanha-ye-Khareji, 42: 5-22.

Pishghdam, R., Shapoori, M. and Shayesteh, S. (2011). "NLP and its relationship with teacher success, gender, teaching experience, and degree: A comparative study", in World Journal of English Language, 1: 2-8.

Porter, A. C. and Brophy, J. (1988). "Synthesis of research on good teaching: Insights from the work of the institute for research on teaching", in Educational Leadership 45: 74-85. 
Randall, W. L. (1995). The Stories We Are: An Essay on Self-creation. Toronto: University of Toronto Press.

Randall, W. L. (1999). "Narrative intelligence and the novelty of our lives", in Journal of Aging Studies, 13: 11-28.

Steele, R. (1986). "Deconstructing history: Toward a systematic criticism of psychological Narratives”, in T. R. Sarbin (ed.), Narrative Psychology: The Storied Nature of Human Conduct. New York: Praeger, 256-275. 